\title{
FORMULATION AND EFFECTIVITY OF THE ANTIOXIDANT GEL PREPARATION CONTAINING ZEAXANTHIN AS ANTI AGING
}

\author{
FAJAR SETIAWAN*, LUSI NURDIANTI, NENG SRI
}

Pharmacy Department, STIKes Bakti Tunas Husada, Jl. Cilolohan 36 Tasikmalaya, West Java, Indonesia, 46115

Email: fajarsetiawan@stikes-bth.ac.id

Received: 18 Aug 2021, Revised and Accepted: 25 Sep 2021

\begin{abstract}
Objective: This study was conducted to determine the IC50 value of zeaxanthin, to know the formula that meets the requirements of the results of physical evaluation of gel preparations, and to know the effectiveness of zeaxanthin gel as an anti-aging on the skin.

Methods: The preparation of this gel is made using zeaxanthin as an active substance with concentrations of 5\%; 7.5\%; and 10\%. Tests conducted are organoleptic test, homogeneity test, $\mathrm{pH}$, spreadability, viscosity, irritation test and cycling test. Tests conducted are organoleptic test, homogeneity test, $\mathrm{pH}$, spreadability, viscosity, irritation test and cycling test. Tests on the effectiveness of zeaxanthin gel preparations against the backs of volunteers' hands were divided into 4 groups as well as testing conducted over $28 \mathrm{~d}$.
\end{abstract}

Results: The results showed a value of IC50 zeaxanthin of $9.044 \mu \mathrm{g} / \mathrm{ml}$, all gel preparations met the requirements of physical evaluation results except in cycling test and test results of the effectiveness of zeaxanthin gel preparations on the backs of volunteer hands there was an increase in humidity with an average increase of $33.17 \% \pm 11.867$ and wrinkles obedience with an average decrease of $47.466 \% \pm 7.115$.

Conclusion: Zeaxanthin can be formulated as gel anti-aging.

Keywords: Antioxidant, Zeaxanthin, Anti-aging, Gel

(C) 2021 The Authors.Published by Innovare Academic Sciences Pvt Ltd. Thisis an open access article under theCCBYlicense (https://creativecommons.org/licenses/by/4.0/) DOI: https://dx.doi.org/10.22159/ijap.2021.v13s4.43846 Journal homepage: https://innovareacademics.in/journals/index.php/ijap

\section{INTRODUCTION}

Aging process is a sure thing that will happen to everyone, but the occurrence of premature aging is something to avoid [1]. Premature aging is the process of aging the skin faster than the time that should happen to anyone, especially in Indonesia with a tropical climate [2]. The process of premature aging is characterized by wrinkles, black spots, fine lines, dry and rough skin [3].

Free radical components (reactive oxygen or ROS) or lipid peroxide (LPO) are involved in the pathogenesis and accelerated development of skin aging in the event of prolonged oxidative stress [4], so antioxidants are indispensable for the body to overcome and prevent oxidative stress [5]. One of the substances that has the potential as an antioxidant is zeaxanthin. Zeaxanthin has antioxidant activity that belongs to a very powerful group of antioxidants. According to (Sindhu et al., 2010), zeaxanthin has an IC50 value of $10 \mu \mathrm{g} / \mathrm{ml}$ where antioxidants belong to the strong group [6].

Oral administration of zeaxanthin may improve acetic acid-induced colitis in rats through antioxidant effects and modulation of proinflammatory cytokines and mediator activity [7]. In addition, zeaxanthin includes carotenoids that can protect the skin from oxidation caused by sun exposure [8]. Lutein and zeaxanthin have been reported to reduce lipid peroxidation and increase moisture in the skin. These results suggest that lutein and zeaxanthin may exhibit protective effects against oxidative light in humans [9].

The route of the drug through topical administration is widely chosen to improve the effectiveness and ease in the application of drugs, one of which is gel preparations. Gel is a semi-solid or semi-solid system of at least two constituents consisting of a tight fence-like mass and covered by liquid [10]. The reason made gel is because gel preparations are much in demand in the drug and cosmetic industry because it has advantages over other preparations that are good spread on the skin, the presence of cold effects when applied to the skin, the release of good drugs, easy to wash [11], does not cause skin marks, and easy in its use [12].

\section{MATERIALS AND METHODS}

\section{Materials}

Zeaxanthin was purchased from Fuji Chemical Industries (Japan). DPPH was purchased from Sigma Aldrich, Polyethylene Glycol 400
(PEG 400) was purchased from Merck (Indonesia). Carbomer was purchased from Brataco, methylparaben and propylparaben (PT. Bratachem), TEA (PT. Bratachem), ascorbic acid p. a was purchased from Merck (Indonesia). All other chemicals used were of pharmaceutical grade.

\section{Test antioxidant activity with DPPH method}

\section{Determination of maximum wavelength of DPPH}

Before the test of antioxidant activity, the determination of maximum wavelength, as much as $5 \mathrm{ml}$ of DPPH solution, is observed absorption at wavelengths of 400-800 $\mathrm{nm}$ [12].

\section{Zeaxanthin antioxidant activity test}

Zeaxanthin is made with a concentration of $1000 \mathrm{ppm}$. From the main solution is made a series concentration of 2 to $10 \mathrm{ppm}$. Each test solution of $1 \mathrm{ml}$ is inserted into the vial. Added DPPH solution $25 \mathrm{ppm}$ as much as $2 \mathrm{ml}$, then incubated for $30 \mathrm{~min}$ and measured absorbance at wavelength $516.5 \mathrm{~nm}$ [12].

\section{Vitamin $C$ antioxidant activity test}

Vitamin C is made with a concentration of $1000 \mathrm{ppm}$. From the main solution is made a series of concentrations of 0.5 to $5 \mathrm{ppm}$. Each test solution of $1 \mathrm{ml}$ is inserted into the vial. Added DPPH solution 25 ppm as much as $2 \mathrm{ml}$, then incubated for $30 \mathrm{~min}$ and measured absorbance at wavelength $516.5 \mathrm{~nm}$ [12].

\section{IC 50 determination}

IC50 value determination of antioxidant activity is obtained from the measurement of absorbance of the series of concentrations that have been made so as to produce \% inhibition that can be calculated based on the formula as follows: [12]

$$
\text { Inhibition [\%] }=\frac{\text { Absorbance of blank-Absorbance of sample }}{\text { Absorbance of Blank }} \times 100 \%
$$

\section{Preparation of zeaxanthin gel preparation}

First, first, dissolve the zeaxanthin with the addition of surfactant and cosurfactant for $30 \mathrm{~min}$ until soluble zeaxanthin is formed, which is characterized by a clear solution [13]. After that, expand the carbopol with warm water $\pm 50{ }^{\circ} \mathrm{C}$ for $30 \mathrm{~min}$ until it expands. Then, 
add triethanolamine little by little until a gel base is formed. Then dissolve methylparaben and propylparaben with glycerin, add to the gel base. Then add zeaxanthin to the gel base. After that, add little by little aqua deion [14].

\section{Preparation formula}

Table 1: Composition of gel zeaxanthin

\begin{tabular}{|c|c|c|c|c|c|}
\hline \multirow{2}{*}{ Material } & \multicolumn{4}{|c|}{ Formula (\% w/v) } & \multirow[t]{2}{*}{ Function } \\
\hline & F0 & F1 & F2 & F3 & \\
\hline Zeaxanthin & - & 5 & 7.5 & 10 & Active substance \\
\hline Carbopol 940 & 0.5 & 0.5 & 0.5 & 0.5 & Gel bases \\
\hline Glycerin & 10 & 10 & 10 & 10 & Humectants \\
\hline Methyl Paraben & 0.18 & 0.18 & 0.18 & 0.18 & Antimicrobial \\
\hline Propyl Paraben & 0.02 & 0.02 & 0.02 & 0.02 & Antimicrobial \\
\hline Triethanolamine & $7 \mathrm{gtt}$ & $7 \mathrm{gtt}$ & $7 \mathrm{gtt}$ & $7 \mathrm{gtt}$ & Alkalizing agent \\
\hline deionized water ad & 100 & 100 & 100 & 100 & Solvent \\
\hline
\end{tabular}

\section{Visual observation and pH determination}

Visual observation includes observation of color, odor, and clarity of gel zeaxanthin. $\mathrm{A} \mathrm{pH}$ of zeaxanthin gel was determined by using a calibrated pH meter (Mettler® Toledo) [15, 16]

\section{Homogeneity test}

The homogeneity test is carried out by applying the sample to a piece of glass or other suitable transparent material, the preparation must show a homogeneous arrangement and there are no visible coarse grains [16].

\section{Viscosity test}

Viscosity test was carried out using a Brookfield Viscometer. The preparation is put into a beaker. Then the spindle is installed 4 . The spindle must be submerged in the test preparation. The viscometer is turned on and it is ensured that the rotor can rotate at a speed of $50 \mathrm{rpm}$. Observed the needle guide from the viscometer that leads to the viscosity scale and then recorded and multiplied by a factor of 100 [17]

\section{Spreadability test}

The preparation was weighed as much as 0.5 grams and then placed in the middle between 2 glass plates, then given a load of $50 \mathrm{~g}, 100 \mathrm{~g}, 200 \mathrm{~g}$ and left for 1 minute and then the actual area was measured [18].

\section{Cycling test}

The cycling test was carried out for 6 cycles. The gel preparation was stored at a cold temperature of $\pm 4^{\circ} \mathrm{C}$ for $24 \mathrm{~h}$ and then removed and then stored at room temperature $\left(25^{\circ} \mathrm{C}\right)$ for $24 \mathrm{~h}$ and placed at a temperature of $\pm 40^{\circ} \mathrm{C}$, this process was counted as 1 cycle [19].

\section{Anti-aging effectiveness test}

The skin condition of the back of the volunteer's hand before the treatment is checked first with test parameters including moisture and skin wrinkles using the moisturizer analyzer and dino-lite Dermatoscopy. Testing of anti-aging activities was conducted on 20 volunteers divided into 4 groups, namely:

Group I: 5 volunteers for blank formula (without active substance)

Group II: 5 volunteers for gel formula with zeaxanthin concentration $5 \%$

Group III: 5 volunteers for gel formula with zeaxanthin concentration of $7.5 \%$

Group IV: 5 volunteers for gel formula with zeaxanthin concentration of $10 \%$.

\section{RESULTS}

Antioxidant activity test is conducted using DPPH method $(1,1-$ difenil-2-pikrilhidrazil). Ic50 value is obtained from linear regression calculation between percent (\%) inhibition with sample concentration. The smaller the IC50, the better its antioxidant activity.

Table 2: IC 50 value of vitamin $\mathrm{c}$ and zeaxanthin

\begin{tabular}{lll}
\hline Sample & IC $_{\mathbf{5 0}}$ & IC $_{\mathbf{5 0}}$ rated intensity \\
\hline Vitamin C & 2.467 & Very strong \\
Zeaxanthin & 9.440 & Very strong \\
\hline
\end{tabular}

Table 3: Organoleptic observations results on weeks 0 to 4

\begin{tabular}{|c|c|c|c|c|}
\hline Preparation & Week & Color & Smell & Form \\
\hline Formula 0 & 0 & Clear & No smell & Gel \\
\hline \multirow[t]{4}{*}{ (base) } & 1 & Clear & No smell & Gel \\
\hline & 2 & Clear & No smell & Gel \\
\hline & 3 & Clear & No smell & Gel \\
\hline & 4 & Clear & No smell & Gel \\
\hline \multirow[t]{5}{*}{ Formula I } & 0 & Yellow & Typical zeaxanthin & Gel \\
\hline & 1 & Yellow & Typical zeaxanthin & Gel \\
\hline & 2 & Yellow & Typical zeaxanthin & Gel \\
\hline & 3 & Yellow & Typical zeaxanthin & Gel \\
\hline & 4 & Yellow & Typical zeaxanthin & Gel \\
\hline \multirow[t]{5}{*}{ Formula II } & 0 & Yellow-Orange & Typical zeaxanthin & Gel \\
\hline & 1 & Yellow-Orange & Typical zeaxanthin & Gel \\
\hline & 2 & Yellow-Orange & Typical zeaxanthin & Gel \\
\hline & 3 & Yellow-Orange & Typical zeaxanthin & Gel \\
\hline & 4 & Yellow-Orange & Typical zeaxanthin & Gel \\
\hline \multirow[t]{5}{*}{ Formula III } & 0 & Orange & Typical zeaxanthin & Gel \\
\hline & 1 & Orange & Typical zeaxanthin & Gel \\
\hline & 2 & Orange & Typical zeaxanthin & Gel \\
\hline & 3 & Orange & Typical zeaxanthin & Gel \\
\hline & 4 & Orange & Typical zeaxanthin & Gel \\
\hline
\end{tabular}


Based on the results obtained, zeaxanthin has activity as an antioxidant and is very powerful. This is in accordance with the literature where a substance is said to have an antioxidant activity group is very strong if the ic 50 value is less than $50 \mathrm{ppm}$, the IC50 strong group is between 50-10 ppm, the moderate group if the IC50 value is between $101-150 \mathrm{ppm}$, the group is weak if the IC50 value is between 150-200 ppm, and the group is very weak when the IC50 value is more than $200 \mathrm{ppm}$ [20].

Organoleptic gel tests are conducted by visually observing the shape, color and smell of the gel. Organoleptic results of the four gel preparation formulas can be seen in table 3 where color differences are obtained due to differences in zeaxanthin concentration.
Homogeneity test aims to see and know the mixing of preparations. Gel preparations should be homogeneous and evenly distributed so as not to cause irritation when applied to the skin. This test is done by placing gel preparations between two glass objects. The results showed that all preparation formulas for $4 \mathrm{w}$ can be said to be homogeneous because when viewed under a microscope, there are no visible fine particles.

$\mathrm{pH}$ testing aimed to determine the acidity or wetness of a preparation. Where when a preparation is too acidic will cause irritation to the skin and will cause heat on the skin or smeared areas and when the preparation is too alkaline can cause the skin to become dry and itchy. Based on the results listed in table 4 for $4 \mathrm{w}$ shows that all formulas are in a good $\mathrm{pH}$ range of 4-7 [21].

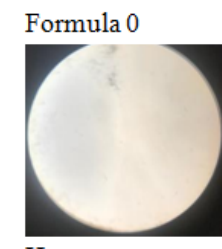

Homogeneous

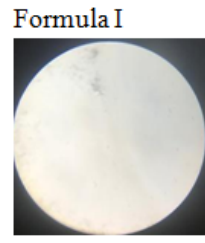

Homogeneous

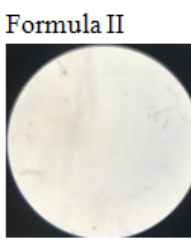

Homogeneous

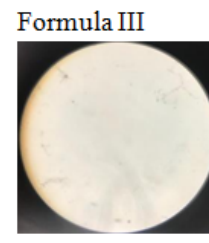

Homogeneous

Fig. 1: Homogeneity test results

Table 4: Observations of $\mathrm{pH}$ measurements in weeks 0 to 4

\begin{tabular}{lllll}
\hline Formula & Observation duration (Week) & & \\
\cline { 2 - 4 } & $\mathbf{0}$ & $\mathbf{1}$ & $\mathbf{2}$ & $\mathbf{3}$ \\
\hline F0 & 6 & 5 & 5 & 5 \\
FI & 5 & 5 & 5 & 5 \\
FII & 5 & 5 & 5 & 5 \\
FIII & 6 & 5 & 5 & 5 \\
\hline
\end{tabular}

Spreadability testing aims to determine the speed of spread or equalization of the gel. From the data table 5 can be seen the spread value in all four formulas has entered the range of requirements, although, during the $4 \mathrm{w}$ of testing, there is a shift in the value of the spread but still in a good range of spreadability. The good spread value of gel is in the range of 5-7 cm [21].

Table 5: Observation results of the spread test in week 0 to 4

\begin{tabular}{|c|c|c|c|c|c|}
\hline \multirow[t]{2}{*}{ Formula } & \multicolumn{5}{|c|}{ Observation duration (Week) } \\
\hline & $\mathbf{0}$ & 1 & 2 & 3 & 4 \\
\hline F0 & $6.0 \mathrm{~cm}$ & $6.0 \mathrm{~cm}$ & $6.4 \mathrm{~cm}$ & $5.8 \mathrm{~cm}$ & $5.6 \mathrm{~cm}$ \\
\hline FI & $5.2 \mathrm{~cm}$ & $5.4 \mathrm{~cm}$ & $5.4 \mathrm{~cm}$ & $5.7 \mathrm{~cm}$ & $5.2 \mathrm{~cm}$ \\
\hline FII & $5.5 \mathrm{~cm}$ & $7.0 \mathrm{~cm}$ & $6.0 \mathrm{~cm}$ & $5.5 \mathrm{~cm}$ & $5.2 \mathrm{~cm}$ \\
\hline FIII & $5.0 \mathrm{~cm}$ & $5.5 \mathrm{~cm}$ & $5.1 \mathrm{~cm}$ & $5.0 \mathrm{~cm}$ & $5.4 \mathrm{~cm}$ \\
\hline
\end{tabular}

Viscosity test aims to see the viscosity of a preparation. The results of the measurement of the viscosity of gel preparations can be seen in fig. 2 where the viscosity of the gel preparations produced shows that the higher the concentration of zeaxanthin viscosity the higher. Although for $28 \mathrm{~d}$ there is an increase and decrease, but it can still be tolerated because it is still in a good viscosity range. The good viscosity range is $2000-4000 \mathrm{cps}$ [22].

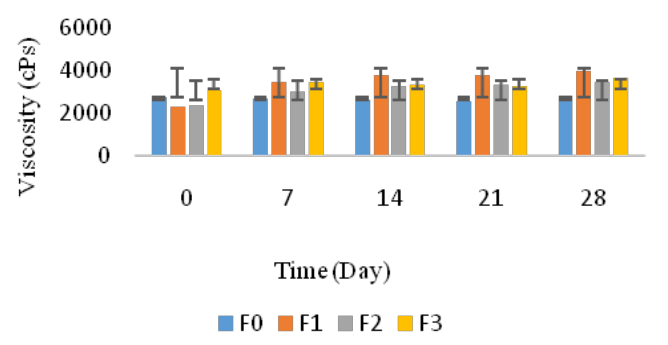

Fig. 2: Viscosity observation results on days 0 to 28
Cycling test aims to determine the physical stability of dosage with the influence of temperature variations. Cycling test evaluation is conducted for 6 cycles. Where in 1 cycle into two stages that are placed in the refrigerator at a temperature of $4{ }^{\circ} \mathrm{C}$ for $24 \mathrm{~h}$, and the next $24 \mathrm{~h}$ placed in the oven at a temperature of $40^{\circ} \mathrm{C}$. Cycling test results can be seen in table 5 . Based on the data obtained shows that only formula II and III are more stable compared to other formulas based on the parameters of $\mathrm{pH}$, color and also smell.

Testing anti-aging activities using skin moisture analyzer (FCM-1) and Dermatoscopy, test parameters include moisture and skin wrinkles. Measurement of anti-aging effectiveness begins by measuring the initial condition of the skin in the area of the back of the hand that has been marked. Then zeaxanthin gel is applied topically every morning and evening. Once a week, measured the change, up to $4 \mathrm{w}$ of use.

Moisture Measurement is done using a skin moisture analyzer tool. The results showed that the moisture on the skin of each group's back before the use of zeaxanthin gel was not all in normal condition. The normal range for humidity is $30-50 \%$ [23]. However, after four weeks of use of zeaxanthin gel there was an increase, 
although the increase was unstable. This could be due to the noncompliance of volunteers in the use of zeaxanthin gel, resulting in reduced therapeutic effects. Based on the results of observations showed that during the four weeks of use of zeaxanthin gel, moisture in the skin of volunteers increased especially in formula III with an average percent increase of 33.17 percent \pm 11.86

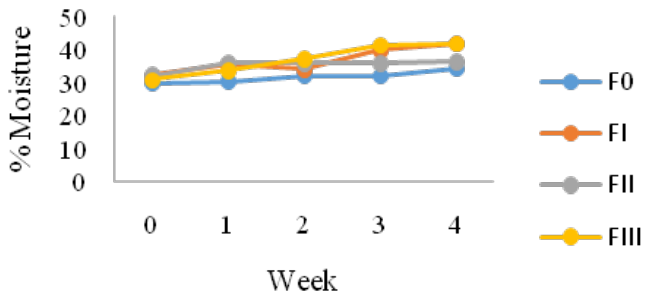

Fig. 3: Results average moisture increase

Wrinkles measurement using Dermatoscopy tool that is by using a 50 -fold magnification lens. The results of the wrinkle measurement can be seen in the picture showing that the skin of the back of the volunteer group's hands before using zeaxanthin gel and after using for $4 \mathrm{w}$ there was a decrease in wrinkles.

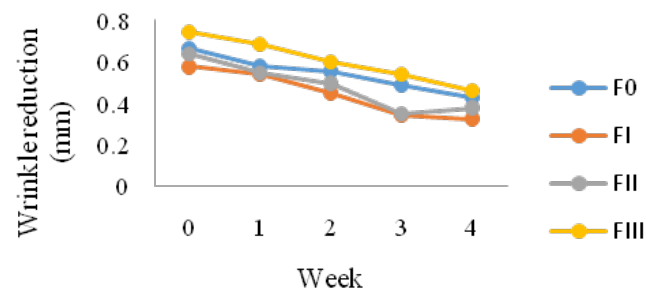

Fig. 4: Average wrinkle reduction results

\section{DISCUSSION}

Antioxidant activity test is conducted using DPPH method (1,1diphenyl-2-pckrylhydrazyl where DPPH method has the advantage of the simple, fast, easy and sensitive analysis method to samples with small concentration [24]. Zeaxanthin and vitamin C solution is measured at a wavelength of $516.5 \mathrm{~nm}$. The antioxidant potential of a compound can be determined by calculating its IC50 nilia (Inhibitory Concentration). The result of IC50 zeaxanthin is 9.044 $\mathrm{ppm}$ is in a very strong range because it is in the range of 0-50 ppm.

In the manufacture of zeaxanthin gel preparations used variations in concentrations in each formula namely FI 5\%, FII 7.5\%, and FIII $10 \% \mathrm{~b} / \mathrm{v}$ using a gel base that is carbomer which will form a mass of gel when $\mathrm{pH}$ 6-8, so to form a clear gel base need to be added TEA that is alkaline. TEA is a compound that will increase the mass $\mathrm{pH}$ of the gel, where a good and clear gel mass is formed so that it is expected not to irritate the skin. Another additional ingredient used is glycerin. Glycerin serves as a humectant and emollient to prevent the occurrence of syneresis and as a moisturizer on the gel.

The results of the evaluation test of zeaxanthin gel preparations obtained organoleptic observations of orange-yellow color with a distinctive smell of zeaxanthin that can form gels with transparent color and provide a cool effect that is easy to wash with water. Homogeneity test results show that all preparation formulas for $4 \mathrm{w}$ can be said to be homogeneous because when viewed under a microscope, there are no visible fine particles. The dosage $\mathrm{pH}$ test shows the acidity level of the preparation is within the good $\mathrm{pH}$ range of 4-7 [21]. The results of the spread of preparations show the ability to spread the preparation when applied to the skin. The good spread value of gel is in the range of 5-7 cm [21]. When a preparation has a high spread value means the greater the spread area that causes the active substances in the preparation is spread evenly and more effective in producing therapeutic effects. This spreadability is influenced by viscosity, the greater the viscosity value of gel preparations, the spread value will decrease and vice versa. When the gel preparation has a low viscosity value, the spread value will be greater. With a large spread, it will make it easier when applying on the skin or make it easier to contact with active substances so that it will soon be absorbed [25]. Cycling test results aim to determine the physical stability of a dosage with the influence of temperature variations. The data obtained shows that zeaxanthin gel formula has good stability during storage at room temperature and temperature $40 \mathrm{C}$ is characterized by the absence of changes of the $\mathrm{pH}$ parameters, color and also smell.

Testing anti-aging activities using skin moisture analyzer (FCM-1) and Dermatoscopy, test parameters include moisture and skin wrinkles. The data showed that there was a significant difference $(\mathrm{P}<0.05)$ between formulas either from increased humidity or from a percent decrease in wrinkle diameter. Increased levels of zeaxanthin in gel formulas showed an increase in better anti-aging activity. It is appropriate to hypothesize that zeaxanthin as a very powerful natural antioxidant, is able to protect the skin against oxidative stress. Many benefits are obtained from the consumption of zeaxanthin as an antioxidant, one of which is the protection of the skin against oxidative stress. Oxidative stress plays an important role in the aging process of the skin and the destruction of the dermal layer in humans. Intrinsic (chronological) and extrinsic (photo-) aging mechanisms occur each, including the emergence of reactive oxygen speci (ROS) through oxidative metabolism and due to exposure to ultraviolet (UV) light from the sun. The formation of ROS can trigger the occurrence of skin aging [26-28]. One of the clinical manifestations that can occur due to skin aging is the appearance of wrinkles on the skin, the appearance of dark spots due to sunlight (skin pigmentation) [29].

\section{CONCLUSION}

Zeaxanthin has an IC50 value of $9.044 \mu \mathrm{g} / \mathrm{ml}$. Gel zeaxanthin meets the requirements of physical evaluation of gel preparations except in cycling test and has the effect of being anti-aging as shown by the presence of a percent increase in average humidity of $33.17 \% \pm 11.867$ and also a percent decrease in the average of $47.466 \% \pm 7.115$.

\section{FUNDING}

Nil

\section{AUTHORS CONTRIBUTIONS}

All the authors contributed equally.

\section{CONFLICT OF INTERESTS}

\section{Declared none}

\section{REFERENCES}

1. Atmaja NS, Marwiyah SE. Pengaruh kosmetika anti aging wajah terhadap hasil perawatan kulit wajah. J Beauty Beauty Health Educ. 2012;1(1):6-9.

2. Dewiastuti M, Hasanah IF. Pengaruh faktor-faktor risiko penuaan dini di kulit pada remaja wanita usia 18-21 tahun. JPM. 2016;10(1)(1:21-5. doi: 10.33533/jpm.v10i1.10.

3. Ratnasari D, Puspitasari RN. Optimasi formula sediaan krim anti-aging dari ekstrak terong ungu (Solanum melongena L.) dan tomat (solanum Lycopersicum L.). J Riset Kesehatan. 2018;7(2):66. doi: 10.31983/jrk.v7i2.3703.

4. Schwartz S, Frank E, Gierhart D, Simpson P, Frumento R. Zeaxanthin-based dietary supplement and topical serum improve hydration and reduce wrinkle count in female subjects. J Cosmet Dermatol. 2016;15(4):e13-20. doi: 10.1111/jocd.12226. PMID 27312122.

5. Irianti T, Nuranto S, Antioksidan KK; 2017.

6. Sindhu ER, Preethi KC, Kuttan R. Antioxidant activity of carotenoid lutein in vitro and in vivo. Indian J Exp Biol. 2010;48(8):843-8. PMID 21341544.

7. El-Akabawy G, El-Sherif NM. Zeaxanthin exerts protective effects on acetic acid-induced colitis in rats via modulation of pro-inflammatory cytokines and oxidative stress. Biomed 
Pharmacother. 2019;111:841-51. doi: 10.1016/ j.biopha.2019.01.001, PMID 30616083

8. Obana A, Gohto Y, Nakazawa R, Moriyama T, Gellermann W, Bernstein PS. Effect of an antioxidant supplement containing high dose lutein and zeaxanthin on macular pigment and carotenoid skin levels. Sci Rep. 2020;10(1):10262. doi: 10.1038/s41598-020-66962-2, PMID 32581313.

9. Palombo P, Fabrizi G, Ruocco V, Ruocco E, Fluhr J, Roberts R, Morganti P. Beneficial long-term effects of combined oral/topical antioxidant treatment with the carotenoids lutein and zeaxanthin on human skin: A double-blind, placebocontrolled study. Skin Pharmacol Physiol. 2007;20(4):199-210. doi: 10.1159/000101807, PMID 17446716.

10. Martin A, Swarbrick J, Cammarata A. Farmasi fisik (KETIGA). UI-Press; 2008.

11. Tsabitah AF, Zulkarnain AK, Wahyuningsih MSH, Nugrahaningsih DAA. Optimasi carbomer, Propilen Glikol, dan Trietanolamin Dalam Formulasi Sediaan Gel Ekstrak Etanol Daun Kembang Bulan (Tithonia diversifolia). Majalah Farmaseutik. 2020;16(2):111-8. doi: 10.22146/farmaseutik.v16i2.45666.

12. Suryani S, Putri AEP, Fitrih WOH. Uji Aktivitas Antioksidan dan Stabilitas Fisik Gel Ekstrak Terpurifikasi Daun Jambu Biji (Psidium guajava L.). Majalah Farmasi,Sains, Dan Kesehatan. 2015;1(2):43-8.

13. Nurdianti L, Aryani R, Indra I. Formulasi dan Karakterisasi SNE (Self Nanoemulsion) astaxanthin dari Haematococcus pluvialis sebagai Super Antioksidan Alami. J Sains Far Klin. 2017;4(1):30-6. doi: 10.29208/jsfk.2017.4.1.168.

14. Supomo S, Komalasari AN. Formulasi gel antioksidan ekstrak kulit buah manggis (garcinia mangostana l.) dengan basis carbopol formulation of mangosteen pericarp ethanolic extract into antioxidants gel (garcinia mangostana l.) with base carbopol. J Ilmiah Ibnu Sina. 2016;1(1):50-60.

15. Nurdianti L, Nurdin A, Pratita ATK, Wulandari WT. Comparison of ethanol emulgel extract activity of Duku fruit peels (Lansium domesticum Corr) with tranexamic acid as a skin lightener. J Glob Pharm Technol. 2020;12(01):244-52.

16. Indriaty S, Rizikiyan Y, Firmansyah D. Formulasi dan uji stabilitas gel antiaging dari kombinasi ekstrak etanol kulit buah naga merah (Achatina fulica) dengan variasi gelling agent carbomer 940. J Pharmacopolium. 2019;2(2):104-11.

17. Zularnain K, Lotion SFS. O/W Dan W/O ekstrak buah mahkota dewa sebagai tabir surya dan uji iritasi primer pada kelinci. Yogyakarta: Gadjah Mada University Press; 2013.
18. Septiani S, Nasrul W, Soraya R. Formulasi sediaan masker gel antioksidan dari ekstrak etanol biji melinjo (Gnetun gnemon Linn.). J Unpad. 2011;1(1):4-24.

19. Nurdianti L, Setiawan F, Indra AR, Mudhakir D, Anggadiredja K. Nanoemulsion based gel formulation of astaxanthin for enhanced permeability: potential as a transdermal drug delivery system. Int J Pharm Sci Rev Res. 2018;52(2):55-9.

20. Molyneux P. The use of the stable free radical diphenylpicrylhydrazyl (DPPH) for estimating antioxidant activity. Songklanakarin J Sci Technol. 2004;26(Dec 2003):211-9.

21. Asrina R, Wahyuni KT. Formulasi gel ekstrak etanol daun jambu biji (Psidium guajva L.) dengan membandingkan basic HPMC dan natrium Alginat. Farmasi Sandi Karsa. 2018;IV(7):15.

22. Irianto IDK, Purwanto P, Mardan MT. Aktivitas antibakteri dan uji sifat fisik sediaan gel dekokta sirih hijau (Piper betle L.) sebagai alternatif pengobatan mastitis sapi. Majalah Farmaseutik. 2020;16(2):202-10. doi: 10.22146/farmaseutik.v16i2.53793. v16i2.53793.

23. Nazliniwaty K, Zebua NF. Nerdy. Antioxidant activity and antiaging gel formulation grapefruit peel (Citrus maxima Merr.) ethanolic extract Department of Pharmaceutical Technology and 2 Department of Pharmaceutical Chemistry. FAC. 2016;8(20):84-94.

24. Karadag A, Ozcelik B, Saner S. Review of methods to determine antioxidant capacities. Food Anal Methods. 2009;2(1):41-60. doi: 10.1007/s12161-008-9067-7.

25. Aprilianti N, Hajrah SY, Polivinilalkohol O. (PVA) sebagai Basis Sediaan gel Antijerawat. Proceeding Mulawarman Pharm Conf; 2020. p. 19.

26. Zouboulis CC, Makrantonaki E. Clinical aspects and molecular diagnostics of skin aging. Clin Dermatol. 2011;29(1):3-14. doi: 10.1016/j.clindermatol.2010.07.001, PMID 21146726.

27. Kammeyer A, Luiten RM. Oxidation events and skin aging. Ageing Res Rev. 2015;21:16-29. doi 10.1016/j.arr.2015.01.001, PMID 25653189.

28. Davinelli S, Bertoglio JC, Polimeni A, Scapagnini G. Cytoprotective polyphenols against chronological skin aging and cutaneous photodamage. Curr Pharm Des. 2018;24(2):99105. doi: 10.2174/1381612823666171109102426, PMID 29119916.

29. Leyden JJ. Clinical features of ageing skin. Br J Dermatol. 1990;122;Suppl 35:1-3. doi: 10.1111/j.13652133.1990.tb16118.x, PMID 2186777. 